\title{
Janusz Taborek
}

Uniwersytet im. A. Mickiewicza w Poznaniu, Wydział Neofilologii

ORCID: 0000-0003-2773-1084 | e-mail: janusz.taborek@amu.edu.pl

\section{Fan, Fußballfan, kibic i pseudokibic jako funkcjonalne ekwiwalenty z perspektywy kookurencji w języku niemieckim i polskim*}

DOI: $10.34739 / \mathrm{clg} .2021 .13 .06$

\section{Wstęp}

W artykule analizie z wykorzystaniem metod lingwistyki korpusowej poddane zostanie pytanie, jakie znaczenie tekstowe wykazują terminy Fußballfan w języku niemieckim oraz jego polskie potencjalne ekwiwalenty tłumaczeniowe. Centralną kwestią jest pytanie, czy (i ewentualnie w jakim stopniu) polskie określenia kibic i pseudokibic są ekwiwalentami funkcjonalnymi niemieckiego Fußballfan w ujęciu D. Dobrovol'skiego (Dobrovol'skij 2015: 277; Mellado Blanco 2019: 76) ${ }^{1}$. Ekwiwalencja funkcjonalna jest ekwiwalencją, która spełnia następujące kryteria:

\footnotetext{
* Niniejszy artykuł, z nieznaczymi modyfikacjami, stanowi tłumaczenie tekstu, który ukazał się w języku niemieckim pod tytułem Zu Bezeichnungen (Fußball-) Fan, kibic und pseudokibic im deutsch-polnischen Vergleich aus Perspektive der Kookkurrenz w monografii zbiorowej pod redakcją Romana Beliutina i Armina Burkhardta, Fankultur und Fankommunikation in nationalen und transnationalen Diskursens, Frankfurt i in. 2021, s. 217-232. Podstawą artykułów jest referat wygłoszony podczas międzynarodowej konferencji Fankultur Und Fankommunikation in nationalen und transnationalen Diskursen dn. 31 maja 2018 r. w Państwowym Uniwersytecie Smoleńskim w Rosji.

1 „(1) Äquivalenz ist aus lexikografischer Sicht in einer Zwischenposition zwischen der Äquivalenz auf der System- und auf der Textebene anzusiedeln.

(2) Äquivalenz muss zumindest zum Teil korpusbasiert zu ermitteln sein.

(3) Äquivalenz kann nicht alle in den Texten aufgefundenen möglichen Übersetzungslösungen berücksichtigen, sondern nur die rekurrenten prototypischen Textäquivalente.

(4) Äquivalenz muss die syntaktischen und semantischen Restriktionen und Präferenzen in beiden Sprachen sowie die Syntagmatik in Betracht ziehen" (Mellado Blanco 2019: 76).
} 
„(1) Ekwiwalencja z perspektywy leksykograficznej zajmuje pozycję między ekwiwalencją na płaszczyźnie systemowej i płaszczyźnie tekstu.

(2) Ekwiwalencja przynajmniej częściowo musi być ustalana na bazie analiz korpusowych.

(3) Ekwiwalencja nie powinna uwzględniać wszystkich rozwiązań tłumaczeniowych stwierdzonych w tekście, ale tylko rekursywne prototypowe ekwiwalenty tekstowe.

(4) Ekwiwalencja musi uwzględniać syntaktyczne i semantyczne ograniczenia oraz preferencje w obydwu językach, jak również relacje syntagmatyczne" (Mellado Blanco 2019: 76).

Punktem wyjścia do poniższych analiz są definicje słownikowe (pkt 2.), a podstawę analizy (pkt 3.) stanowią korpusowe analizy kookurencji, która pozwala na ustalenie signifikantnych wyrazów i grupy wyrazów współwystępujących z jednostką analizowaną, a tym samym najczęstsze ko(n)teksty występowania analizowanej jednostki.

\section{Fußballfan i kibic - analiza leksykograficzna i próba typologii}

\subsection{Fan i Fußballfan w języku niemieckim}

W języku niemieckim preferowanym i najczęściej występującym określeniem kibica piłkarskiego jest Fußballfan², złożenie determinatywne z komponentem głównym Fan. Leksem Fan, który przejęty został do języka niemieckiego z amerykańskiej angielszczyzny w połowie XX w. (por. Pfeifer 1993), pochodzi od łac. fanaticus oznaczającego 'zachwyconego zwolennika, zachwyconą zwolenniczkę czegoś' (DUW 575). Leksykograficzny przykład ilustrujący użycie leksemu - die [Fan]s stürmtenauf den Fußballplatz [kibice ruszyli na boisko piłkarskie] przejęty został z języka sportu, jednak samo określenie nie odnosi się jedynie do domeny sportu, co potwierdza leksykograficzna definicja w słowniku Wahriga, czyli 'ktoś, kto jest znacząco zachwycony, szczególnie sportem lub jazzem'3 (WDG). Pierwsze konstatacje dotyczące określenia Fan wynikające z analizy definicji słownikowych brzmią: (a) określenie Fan odnosi się nie tylko do domeny sportu i (b) compositum Fußballfan jest hiponimem określenia Fan. Fußballfan definiowany jest w słowniku Dudena jako 'namiętny zwolennik, namiętna zwolenniczka piłki nożnej' ${ }^{4}$ (DUW 655).

\footnotetext{
2 Według danych korpusowych Niemieckiego Korpusu Referencyjnego (DeReKo).

3 ,jmd., der für etw. überschwänglich begeistert ist, besonders für Sport und Jazz" (WDG).

${ }^{4}$ „ein[en] leidenschaftliche[n] Anhänger, eine leidenschaftliche Anhängerin des Fußballs” (DUW).
} 
Burkhardt (2006: 124) podaje dla leksemu Fußballfan dwa warianty i rozróżnia między „osobą zainteresowaną piłką nożną, która często ogląda mecze na stadionie lub w telewizji”5 $\mathrm{i}$ „zagorzałym zwolennikiem klubu lub zespołu (prawdziwym kibicem)"6. W Uniwersalnym słowniku Dudena wymienione są dalsze złożenia z rzeczownikiem Fußball jako komponentem determinującym, a mianowicie Fußballanhänger, 'zwolennik piłki nożnej' i FußballFreund 'przyjaciel piłki nożnej', w definicjach tychże leksemów nie są notowane przymiotniki konotujące emocje - ani begeistert 'zachwycony', ani leidenschaftlich 'namiętny'. Internetowa edycja słownika Dudena odnotowuje ponadto złożenie Fußballrowdy w znaczeniu „kibica piłkarskiego, który zachowuje się jako chuligan”7 (Duden online), podczas gdy Rowdy oznacza „[młodą, najczęściej męską] osobę, która publicznie zachowuje się grubiańsko i stosuje przemoc"8. Odwołanie do osób „młodych” jest zgodne z definicją fana w słowniku etymologicznym Pfeifera, w którym określany jest on jako „młody, zachwycony zwolennik" (Pfeifer 1993) ${ }^{9}$.

Podsumowując przegląd definicji słownikowych i prezentacji leksykograficznej, zauważalna jest różnica między zasadniczo neutralnym Fußballfan (Fußballanhänger, Fußballfreund) a wykazującym negatywne konotacje Fußballrowdy (Hooligan, Hool). Dalszymi określeniami grup kibiców są w języku niemieckim Kuttenfans, Ultras, Allesfahrer i Groundhopper. Z socjologicznej perspektywy Pilz (2005) odróżnia tzw. „normalnych” kibiców piłkarskich (Normalos) od grup Kuttefans, Ultras i Hooligans.

Określenie Kuttenfan pochodzi od noszonej przez kibiców kurtki (niem. Kutte), w latach 80. popularnie nazywanej „kataną”, z licznymi naszywkami (por. Burkhardt 2006: 176), i obejmuje grupy „starszych” kibiców, nawiązując do subkultur „harleyowców” i zwolenników muzyki heavy-metalowej. To kibice, którzy „chodzą na stadion, aby oglądać zwycięstwo swojej drużyny, namiętnie i bezwarunkowo wspierają swoją drużynę i walczą o honor swojej drużyny" (Pilz 2005: 6) ${ }^{10}$. Określeniem ultras nazywane są grupy kibicowskie

\footnotetext{
5 „Fußballinteressierte[r], der häufig im Stadion o. im Fernsehen Spiele ansieht” (Burkhardt 2006: 124).

6 „,begeisterte[r] Anhänger eines Vereins o. einer Auswahl, (echte[r]) Fan” (Burkhardt 2006: 124).

7 „Fußballfan, der sich als Rowdy benimmt” (Duden-Online).

8 „[jüngere, meist männliche] Person, die sich in der Öffentlichkeit flegelhaft aufführt und gewalttätig wird" (Duden online).

9 ,jugendlicher begeisterter Anhänger” (Pfeifer 1993).

10 „Kuttenfans gehen ins Stadion, um ihre Mannschaft gewinnen zusehen, sie stehen leidenschaftlich und bedingungslos hinter ihrer Mannschaft und kämpfen für die Ehre ihrer Mannschaft" (Pilz 2005: 6).
} 
zajmujące się głównie zorganizowanym dopingiem drużyny podczas meczu. „Wzorując się na scenie ultrasów we Włoszech, celem działania tej grupy jest stworzenie na stadionie atmosfery nowego rodzaju. Do repertuaru tej grupy należą choreografie, pokazy w sektorze, flagi z napisami, fany, nowe przyśpiewki i inne rytuały wprowadzające odpowiedni nastrój"11 (Pilz 2005: 7).

Niejako w poprzek istniejących grup umotywowanych historycznospołecznie wykształciła się grupa wyjazdowiczów (niem. Allesfahrer) oznaczająca tych kibiców, którzy swojej drużynie „towarzyszą w miarę możliwości podczas wszystkich meczów wyjazdowych” (Burkhardt 2006: 27). Swego rodzaju „turystyką stadionową” niezależną i zazwyczaj niepowiązaną z dopingowaniem jakiejkolwiek drużyny stanowi kultura kibiców tzw. Groundhopper, których celem jest odwiedzenie (możliwie jak największej liczby) stadionów piłkarskich. I wreszcie wymienić należy prawdopodobnie najliczniejszą grupę kibiców telewizyjnych (niem. Fernsehzuschauer), która w słowniku języka piłki nożnej A. Burkhardta umieszczona został pod drugim znaczeniem.

\subsection{Kibic w języku polskim}

Język polski dysponuje neutralnym określeniem fan, które według definicji słownikowej oznacza 'osob[ę] wykazując[ą] dużo zainteresowania i zaangażowania emocjonalnego w stosunku do określonego zespołu muzycznego, piosenkarza, sportowca, gatunku muzycznego, jakiejś dyscypliny sportu lub czegoś innego' (WSJP). Obok leksemu fan, które posiada szeroki zakres domen (sport, muzyka) oraz jest anglicyzmem stosunkowo „młodym” w systemie językowym, w polszczyźnie używany jest w kontekście piłkarskim leksem kibic.

Wyraz kibic jest germanizmem, najprawdopodobniej przejętym do polszczyzny za pośrednictwem jidisz, które pochodzi od niem. Kiebitz 'kawka' i jeszcze w roku 1927 oznaczało mężczyznę przyglądającego się grze w karty. We współczesnej polszczyźnie zdaniem autorów WSJP rozróżnia się kibica piłki nożnej od kibica partii politycznej. W relewantnym dla dalszych rozważań pierwszym znaczeniu to 'osoba interesująca się karierą tego zawodnika lub tej drużyny, z którymi sympatyzuje, dopingująca ich na zawodach sportowych' (WSJP).

\footnotetext{
11 „Angelehnt an die Ultraszenen in Italien ist es Ziel dieser Fans, eine neue Art der Atmosphäre in die Stadien zubringen. Zu ihrem Repertoire gehören Choreografien, Kurvenshows, Spruchbänder, Schwenkfahnen, Doppelhalter, neue Gesänge und andere Stimmungsrituale" (Pilz 2005: 7).
} 
Słowoforma kibic wchodzi w relacje słowotwórcze, będąc bazą dla nowych rzeczowników z przedrostkami (pseudokibic), przyrostkami (kibol), przymioników (kibicowski) i czasowników (kibicować).

Równolegle ze słowem kibic od ponad dwóch dekad funkcjonuje negatywne nacechowanie wyrazu kibol, analogicznie do robol czy psychol (por. Duda 2008: 248; Janik 2018). Pejoratywne konotacje sufiksu -ol nie dotyczą gwary poznańskiej, w której kibol konotowany jest neutralnie, podobnie jak brachol 'brat' czy karusol 'karuzela'. Stąd kibice poznańskiej drużyny Lech Poznań sami nazywają się kibolami, podczas gdy słownik definiuje kibola jako 'fanatyczn [ego] kibic[a] określonej drużyny sportowej' (WSJP), opatrując definicję znacznikiem użycia pejoratywnego. Określenie kibol wydaje się zastępować w mediach powstałe w latach 70. określenie szalikowiec i od lat 90. - charakteryzujących się wzmożeniem zamieszek na piłkarskich stadionach w Polsce - utożsamiane z anglojęzycznym chuliganem.

Utworzony za pomocą przedrostka pseudo- rzeczownik pseudokibic służy odróżnieniu kibica „normalnego” (por. Burkhardt 2006) od kibica wywołującego zamieszki i stosującego przemoc (por. Żmigrodzki 2007; Duda 2008: 245 n.). Prefiks pseudo- posiada negatywne konotacje i w tym sensie pseudokibic oznacza kogoś, kto mecz piłkarski traktuje jako pretekst i okazję do wywoływania zamieszek i burd.

Szeroka paleta określeń kibica piłkarskiego we współczesnej polszczyźnie obejmuje internacjonalizm ultras, który w język polskim przez tę grupę kibicowską odnoszony jest do kibiców organizujących doping na stadionie, podczas gdy w mediach grupa ta utożsamiana jest z kibolami lub pseudokibicami, presuponując zachowania przemocowe. Ciekawe z perspektywy asymilacji zapożyczeń do systemu językowego polszczyzny jest przypisanie rodzaju męskiego do używanej w liczbie pojedynczej wyjściowej formy w liczbie mnogiej ultras, co nastąpiło zapewne przez analogię do brudas czy golas. Forma żeńska ultraska i liczba mnoga ultrasi wskazują na pełną asymilację do polskiej fleksji.

Określenie wyjazdowicz, ekwiwalent niemieckiego Allesfahrer, utworzone zostało w języku polskim od rzeczownika wyjazd i oznaczającego wykonawcę przyrostka -owicz.

Specyficzny kulturowo i językowo pozostaje leksem piknik oznaczający w żargonie kibiców piłkarskich widza odwiedzającego stadion celem obejrzenia widowiska sportowego bez zaangażowania $\mathrm{w}$ dopingowanie 
drużyny. Atrybutami przedstawiciela tej grupy kibicowskiej są szal, kapelusz lub czapka, trąbka, a często karykaturalnie również wąsy.

Podsumowując prezentację palety określeń sympatyków piłki nożnej, uwagę zwracają różnice kulturowe w terminologii niemieckiej i polskiej. Dotyczą one kulturowo nacechowanego słowa Kuttenfan w niemczyźnie oraz szalikowiec i piknik w polszczyźnie. Pozorna analogia i pełna ekwiwalencja występują pomiędzy określeniami (Fußball)Fan i kibic (piłkarski). Z tego względu w dalszej części artykułu przedstawiona zostanie analiza kontekstów użycia określeń Fußballfan i Fan oraz kibic, a podstawę analizy stanowi kookurencja (współwystępowanie) ustalana na bazie zbiorów korpusowych niemczyzny i polszczyzny współczesnej.

\section{Kookurencja}

W poniższych rozważaniach wychodzi się od założenia, że znaczenie słowa odzwierciedla się w jego użyciu i współwystępowaniu z innymi wyrażeniami w ko(n)tekście, zgodnie z twierdzeniem L. Wittgensteina o znaczeniu słowa i tradycją brytyjskiego kontekstualizmu (J.R. Firth, J. Sinclair i inni). Najprostszą metodą zbadania ko(n)tekstu wydaje się być korpusowa analiza kookurencji (por. Mellado Blanco 2019: 76). Pod pojęciem kookurencji rozumiane jest „współwystępowanie elementów językowych różnych klas” 12 (Bußmann 2008: 375). Tak zdefiniowana kookurencja obejmuje szeroką paletę środków współwystępujących i obejmuje np. umotywowane leksykalnie kolokacje, umotywowane gramatycznie koligacje w ujęciu Sinclaira, ale również koordynacje czy partykuły. Ustalone w sposób półautomatyczny elementy współwystępujące grupowane są ze względu na ich funkcje składniowe, a następnie wewnątrz funkcji składniowych na grupy semantyczne, co pozwala na ustalenie preferowanych wzorców syntagmatycznych analizowanej jednostki (por. Bubenhofer 2015: 486; Taborek 2020). Dla poddanych analizie rzeczowników Fan, Fußballfan, kibic i pseudokibic celem jest ustalenie, jakie wyrazy i grupy wyrazowe przynależne do kategorii przymiotnika i czasownika najczęściej współwystępują z badaną jednostką, czyli:

a) przymiotnik i grupa przymiotnikowa w funkcji przydawki (Adj + N!), czyli pytanie: jaki jest kibic?

\footnotetext{
12 „Miteinandervorkommen von sprachlichen Elementen verschiedener Klassen” (Bußmann 2008: 375).
} 
b) czasownik z analizowaną jednostką jako podmiot $\left(\mathrm{N}_{\text {sub }}+\mathrm{V}\right)$, czyli pytanie: co robi kibic?

c) czasownik z analizowaną jednostką jako dopełnienie ( $\left.\mathrm{V}+\mathrm{N}_{\mathrm{obj}}\right)$, czyli pytanie: co się dzieje z kibicem?

Materiał poddany analizie stanowi korpus DWDS ${ }^{13}$ dla języka niemieckiego wraz z narzędziem DWDS-Profil celem ustalania kolokacji, a dla języka polskiego korpus plTenTen i narzędzie WordSketch grupy SketchEngine. Wybór ten gwarantuje porównywalność uzyskanych wyników ze względu wartość statystyczną LogDice będącą podstawą zestawienia list frekwencyjnych. Standaryzacja za pomocą wartości LogDice pozwala również na pominięcie kryterium wielkości korpusu jako wartości porównywalnej.

W poniższych analizach w punktach 3.1.-3.3. przedstawione zostaną wyniki analiz kookurencji trzech powyższych grup od a) do c) dla wyrazów Fan i Fußballfan oraz ich porównanie z danymi wynikowymi dla słowa kibic.

\subsection{Przydawka przymiotnikowa (ADJ + N), czyli jaki jest kibic?}

Cechy kibica w jego językowym obrazie przedstawiają przydawki przymiotnikowe leksemów Fan, Fußballfan i kibic ${ }^{14}$, spośród których przydawki o najwyższej częstotliwości przedstawione zostały w tabelach 1 i 2.

Tabela 1. Kookurencja (przydawki przymiotnikowej) leksemów niemieckich Fußballfan, Fan

\begin{tabular}{|l|l|c|l|c|}
\hline Lp. & \multicolumn{1}{|c|}{ Fan } & LogDice & \multicolumn{1}{|c|}{ Fußballfan } & Log-Dice \\
\hline 1. & mitgereist 'przybyły' & 9,6 & $\begin{array}{l}\text { randalierend } \\
\text { 'wywołujący awantury' }\end{array}$ & 8,7 \\
\hline 2. & treu 'wierny' & 9,5 & $\begin{array}{l}\text { gewaltbereit } \\
\text { 'skłonny do przemocy' }\end{array}$ & 8,5 \\
\hline 3. & begeistert 'zachwycony' & 8,8 & bekennend 'wyznający' & 7,6 \\
\hline 4. & weiblich 'żeński' & 8,7 & eingefleischt 'zagorzały' & 7,6 \\
\hline 5. & eingefleischt 'XXX' & 8,3 & feiernd 'świętujący' & 7,4 \\
\hline 6. & $\begin{array}{l}\text { enttäuscht } \\
\text { 'rozczarowany' }\end{array}$ & 8,2 & grölend 'krzyczący' & 7,0 \\
\hline 7. & $\begin{array}{l}\text { gegnerisch } \\
\text { 'drużyna przeciwna' }\end{array}$ & 8,2 & begeistert 'zachwycony' & 6,7 \\
\hline 8. & gewaltbereit 'agresywny' & 8,0 & angetrunken 'podpity' & 6,7 \\
\hline
\end{tabular}

${ }^{13}$ Korpus DWDS (Digitales Wörterbuch der Deutschen Sprache), https://www.dwds.de/. 


\begin{tabular}{|l|l|c|l|c|}
\hline 9. & $\begin{array}{l}\text { aufgebracht } \\
\text { 'zdenerwowany' }\end{array}$ & 7,8 & gewalttätig 'agresywny' & 6,7 \\
\hline 10. & jubelnd 'świętujący' & 7,8 & leidenschaftlich 'namiętny' & 6,5 \\
\hline
\end{tabular}

Źródło: opracowanie własne na podstawie dwds.de

Tabela 2. Kookurencja (przydawki przymiotnikowej) leksemu polskiego kibic ${ }^{15}$

\begin{tabular}{|c|l|c|}
\hline Lp. & Kibic & LogDice \\
\hline 1. & piłkarski & 7,8 \\
\hline 2. & wierny & 7,7 \\
\hline 3. & prawdziwy & 7,2 \\
\hline 4. & miejscowy & 6,5 \\
\hline 5. & zagorzały & 6,4 \\
\hline 6. & sportowy & 6,3 \\
\hline 7. & przyjezdny & 6,3 \\
\hline 8. & wspaniały & 5,8 \\
\hline 9. & normalny & 5,6 \\
\hline 10. & fanatyczny & 5,5 \\
\hline
\end{tabular}

Źródło: opracowanie własne na podstawie sketchengine.eu

Przymiotniki wykazujące najwyższą częstotliwość współwystępowania z leksemami Fußballfan i kibic dają się pogrupować ze względu na ich znaczenie (domenę) i funkcję, a mianowicie odnoszą się one do:

a) specyfikacji (mitgereister/gegnerischer/weiblicher Fan, miejscowy/ piłkarski/sportowy/normalny/przyjezdny kibic);

b) wierności (treuer Fan, wierny/prawdziwy kibic);

c) fanatyzmu i namiętności (eingefleischter Fan, zagorzały/fanatyczny kibic;

d) emocji pozytywnych i negatywnych (enttäuschter/begeisterter/ jubelnder/aufgebrachter, wspaniały kibic);

e) przemocy, agresji i alkoholu (gewaltbereit, gewalttätig, randalierend, angetrunken).

Zwraca uwagę fakt, że kookurencja leksemów Fußballfan/Fan i kibic wykazuje daleko idącą konwergencję w punktach od b) do d), to znaczy

\footnotetext{
15 Ustawienia: trzy wyrazy tekstowe z lewej, trzy wyrazy tekstowe z prawej, włączona lematyzacja.
} 
w odniesienie do fanatyzmu, namiętności, emocji i wierności. Konwergencja dotyczy w znacznym stopniu także specyfikacji analizowanych leksemów ujętych w punkcie a). W charakterystyce polskiego leksemu kibic zwraca uwagę brak atrybutów negatywnych odnoszących się zarówno do działania pod wpływem alkoholu, jak i do działań przemocowych uwzględnionych $\mathrm{w}$ powyższym zestawieniu $\mathrm{w}$ punkcie e). Ta różnica między niemieckimi a polskim leksemami wynikająca z analizy kontekstów i użycia potwierdza analiza kombinacji ww. leksemów z czasownikami.

\subsection{Podmiot gramatyczny $\left(\mathrm{N}_{\mathrm{sub}}+\mathrm{V}\right)$, czyli co robi kibic?}

Odpowiedź na powyższe pytanie o aktywność kibica z analizowanym leksemem w syntaktycznej funkcji podmiotu gramatycznego dają czasowniki wykazujące najwyższą częstotliwość współwystępowania z leksemami Fan, Fußballfan i kibic.

Tabela 3. Czasowniki współwystępujące z leksemami Fan i Fußballfan w funkcji podmiotu (dwds.de)

\begin{tabular}{|c|l|c|l|c|}
\hline Lp. & \multicolumn{1}{|c|}{ Fan } & LogDice & \multicolumn{1}{|c|}{ Fußballfan } & LogDice \\
\hline 1. & feiern 'świętować' & 9,2 & $\begin{array}{l}\text { randalieren 'wszczynać } \\
\text { rozruby' }\end{array}$ & 7,7 \\
\hline 2. & jubeln 'radować się, świętować' & 8,1 & mitfiebern 'dopingować' & 6,9 \\
\hline 3. & singen 'śpiewać' & 8,0 & pilgern 'pielgrzymować' & 5,8 \\
\hline 4. & stürmen 'atakować' & 7,5 & $\begin{array}{l}\text { jubeln 'radować się, } \\
\text { świętować' }\end{array}$ & 5,4 \\
\hline 5. & skandieren 'skandować' & 7,4 & verfolgen 'śledzić' & 4,9 \\
\hline 6. & pfeifen 'gwizdać' & 7,4 & feiern 'świętować' & 4,5 \\
\hline 7. & rufen'16 'wołać' & 7,3 & stürmen 'atakować' & 4,4 \\
\hline 8. & warten 'czekać' & 7,3 & gucken 'oglądać, patrzeć się' & 4,2 \\
\hline 9. & freuen 'cieszyć się' & 7,3 & freuen 'cieszyć (się)' & 3,4 \\
\hline 10. & brüllen 'ryczeć, wrzeszczeć' & 7,3 & reisen 'podróżować' & 3,3 \\
\hline
\end{tabular}

Źródło: opracowanie własne na podstawie dwds.de

\footnotetext{
16 Narzędzie obliczania kolokacji DWDS Wortprofil podaje formę w czasie przeszłym Präteritum, czyli riefen.
} 
Tabela 4. Czasowniki współwystępujące z leksemem kibic w funkcji podmiotu (SketchEngine.com)

\begin{tabular}{|c|l|c|}
\hline Lp. & \multicolumn{1}{|c|}{ Fan } & LogDice \\
\hline 1. & zgromadzić (się) & 7,6 \\
\hline 2. & dopingować & 7,0 \\
\hline 3. & oglądać & 6,6 \\
\hline 4. & obejrzeć17 & 6,5 \\
\hline 5. & przyjechać & 6,2 \\
\hline 6. & czekać & 6,1 \\
\hline 7. & liczyć & 5,9 \\
\hline 8. & zobaczyć & 5,7 \\
\hline 9. & przychodzić & 5,6 \\
\hline 10. & skandować & 5,5 \\
\hline
\end{tabular}

Źródło: opracowanie własne na podstawie sketchengine.eu

Konwergencja pomiędzy najczęstszymi kookurencjami leksemów (Fußball) Fan i kibic dotyczy następujących grup semantycznych:

a) radość (feiern, jubeln, (sich) freuen; dopingować);

b) doping (singen, skandieren, rufen; skandować);

c) oglądanie (verfolgen, gucken; oglądać/obejrzeć, zobaczyć);

d) podróżowanie (reisen; przychodzić, przyjechać);

e) (o)czek(iw)anie (warten; czekać, liczyć).

Rozbieżności wśród uzyskanych kookurencji dotyczą - podobnie jak w przypadku atrybutów przydawkowych - czasowników z pola semantycznego przemocy, czyli stürmen 'atakować' (często współwystępujący zarówno z leksemem Fan, jak i Fußballfan), brüllen 'wrzeszczeć' oraz zdecydowanie na pierwszym miejscu notowany czasownik randalieren 'wszczynać awantury'.

\subsection{Dopełnienie $\left(\mathrm{V}+\mathrm{N}_{\mathrm{obj}}\right)$, czyli czego doświadcza kibic?}

Odpowiedź na pytanie, czego doświadcza kibic i co się z nim dzieje, stanowią kookurencje rzeczownikowe o najwyższej częstotliwości współwystę-

\footnotetext{
17 Czasowniki oglądać (ndk) i obejrzeć (dk) tworzą parę aspektową i powinny być analizowane jako jeden czasownik. W takim przypadku do listy dziesięciu najczęściej współwystępujących czasowników dołączony zostałby czasownik oczekiwać. Na kolejnych miejscach listy frekwencyjnej za czasownikiem oczekiwać pojawiają się wspierać, zasiąść i śpiewać, których niemieckie ekwiwalenty wykazują wyższą frekwencję.
} 
powania, które występują w funkcji gramatycznego dopełnienia - biernikowego lub przyimkowego - wymaganego przez analizowane leksemy (Fußball)fan i kibic. W analizie tej ze względu na jej cel abstrahuje się od „perspektywizacji”, czyli rozróżnienia, czy dopełnienie biernikowe realizowane jest jako dopełnienie w zdaniu w stronie czynnej, czy też w wyniku transformacji pasywno-aktywnej realizowane jest jako podmiot gramatyczny z orzeczeniem w stronie biernej.

Tabela 5. Czasowniki współwystępujące z leksemami Fan i Fußballfan w funkcji dopełnienia

\begin{tabular}{|c|l|c|l|c|}
\hline Lp. & \multicolumn{1}{|c|}{ Fan } & LogDice & \multicolumn{1}{|c|}{ Fußballfan } & LogDice \\
\hline 1. & begeistern 'zachwycać' & 8,8 & begeistern 'zachwycać' & 5,3 \\
\hline 2. & $\begin{array}{l}\text { bedanken (bei) } \\
\text { 'dziękować (komuś)' }\end{array}$ & 8,0 & locken 'wabić, przyciągać' & 4,1 \\
\hline 3. & $\begin{array}{l}\text { auspfeifen (von) } \\
\text { 'wygwizdywać (przez) ' }\end{array}$ & 8,0 & festnehmen 'zatrzymywać' & 3,8 \\
\hline 4. & $\begin{array}{l}\text { enttäuschen } \\
\text { 'rozczarować' }\end{array}$ & 7,9 & versorgen 'zaopatrywać' & 3,5 \\
\hline 5. & versöhnen 'pojednać' & 7,8 & freuen 'cieszyć' & 2,8 \\
\hline 6. & zuwinken 'pomachać' & 7,7 & $\begin{array}{l}\text { verurteilen 'skazywać, } \\
\text { osądzać' }\end{array}$ & 2,1 \\
\hline 7. & $\begin{array}{l}\text { entschuldigen (bei) 'uspra- } \\
\text { wiedliwiać się (u)' }\end{array}$ & 7,4 & drohen 'grozić' & 1,9 \\
\hline 8. & verzaubern 'oczarowywać' & 7,4 & bitten 'prosić' & 1,8 \\
\hline 9. & locken 'wabić, przyciągać' & 7,0 & beschäftigen 'zajmowac' & 1,7 \\
\hline 10. & beruhigen 'uspokajać' & 6,9 & sprechen 'mówić' & 1,5 \\
\hline
\end{tabular}

Źródło: opracowanie własne na podstawie dwds.de

Tabela 6. Czasowniki współwystępujące z leksemem kibic w funkcji dopełnienia

\begin{tabular}{|c|l|c|}
\hline Lp. & Fan & LogDice \\
\hline 1. & zawieść & 6,3 \\
\hline 2. & podziękować & 6,1 \\
\hline 3. & czekać & 6,1 \\
\hline 4. & dostarczyć & 5,5 \\
\hline 5. & przyciągać & 5,5 \\
\hline
\end{tabular}




\begin{tabular}{|c|l|l|}
\hline 6. & pozdrawiać & 5,3 \\
\hline 7. & pokazać & 5,3 \\
\hline 8. & sprawić & 5,3 \\
\hline 9. & szanować & 5,1 \\
\hline 10. & spodziewać się & 5,0 \\
\hline
\end{tabular}

Źródło: opracowanie własne na podstawie sketchengine.eu

Porównanie najczęstszych współwystępujących czasowników pozwala stwierdzić pełną konwergencję i obecność semantycznie tożsamych czasowników prostych w języku niemieckim i polskim:

- sichbedanken (bei) 'dziękować (komuś)'- podziękować,

- enttäuschen 'rozczarować'- zawieść,

oraz w kilku dalszych przypadkach pełnej ekwiwalencji czasowników prostych w języku niemieckim i zwrotów werbonominalnych w języku polskim, na przykład:

- freuen 'cieszyć' - sprawiać radość;

- enttäuschen 'rozczarować' - sprawiać zawód.

Pozorny brak odpowiedników polskich dla czasownika begeistern 'zachwycać', który wykazuje najwyższą częstotliwość współwystępowania zarówno z leksemem Fußballfan, jak i Fan wyjaśnia głębsza analiza współwystępowania czasowników z tab. 6 , która wskazuje na łączliwość czasownika dostarczać z rzeczownikami, a mianowicie dostarczać emocji, dostarczać radości i dostarczać przeżyć. Ponieważ zwroty werbonominalne dostarczać emocji i dostarczyć przeżyć mogą odnosić się zarówno do pozytywnych, jak i negatywnych emocji, stanowią ekwiwalenty czasownika enttäuschen 'rozczarowywać'.

W języku polskim w wynikach analizy czasowników współwystępujących z leksemem kibic jako dopełnieniem - analogicznie do wyników analizy w punktach 3.1., 3.2. - nie obserwuje się czasowników konotowanych pejoratywnie i tym samym potencjalnych funkcjonalnych ekwiwalentów niemieckich czasowników lock en 'wabić', festnehmen 'zatrzymywać', verurteilen 'skazywać', druhen 'grozić' i vorgehenn (gegen) 'postępować (przeciw)' z tab. 5.

\section{Analiza kookurencji leksemu pseudokibic}

Próbą odpowiedzi na pytanie, dlaczego w wynikach analiz polskiego leksemu kibic odnotowano brak leksemów odnoszących się do przemocy, jest przypuszczenie, że w kontekstach „negatywnych” leksemów Fan i Fussballfan 
w polszczyźnie używany jest inny leksem niż kibic i że funkcję tę przejmuje pseudokibic. Tym samym leksem pseudokibic poddany zostaje analizie analogicznej do przeprowadzonej analizy kookurencji leksemu kibic w punktach 3.1.-3.3. Analiza przeprowadzona jest za pomocą narzędzi grupy SketchEngine i korpusu plTenTen12.

Tabela 7. Przydawki przymiotnikowe leksemu pseudokibic (SketchEngine, plTenTen)

\begin{tabular}{|c|l|c|}
\hline Lp. & Adjektiv & LogDice \\
\hline 1. & stadionowy & 6,7 \\
\hline 2. & chuligański & 6,5 \\
\hline 3. & zatrzymany & 5,1 \\
\hline 4. & zamaskowany & 5,0 \\
\hline 5. & krewki & 4,8 \\
\hline 6. & agresywny & 4,7 \\
\hline 7. & rasistowski & 4,5 \\
\hline 8. & piłkarski & 4,4 \\
\hline 9. & bandycki & 3,7 \\
\hline 10. & rozjuszony & 3,7 \\
\hline
\end{tabular}

Źródło: opracowanie własne na podstawie sketchengine.eu

Spośród kolokacji przymiotnikowych (tab. 7) dwie mają właściwości specyfikujące i tym samym nie wykazują konotacji pozytywnych ani negatywnych, to przymiotniki stadionowy i piłkarski, por. przykłady [1] i [2].

[1] Czekać będq (miejsca w areszcie) na stadionowych pseudokibiców z Polski i zagranicy (gdansk.naszemiasto.pl).

[2] [...] Jedną z grup uczestniczq̨cych $w$ zamieszkach byli piłkarscy pseudokibice (opcjanaprawo.pl).

Pozostałe przymiotniki odnoszą do łamania prawa zatrzymany), jak w przykładzie [3] lub wykazują konotacje jednoznacznie negatywne, np. zamaskowany - jak w przykładzie użycia [4] - agresywny czy rozjuszony.

[3] Policjanci zatrzymuja najbardziej agresywnych pseudokibiców (pb.pl).

[4] Zamaskowani pseudokibice rzucali w funkcjonariuszy kamieniami i butelkami (rzeszowska24.pl). 
Zwraca uwagę, że przymiotniki polskie współwystępujące relatywnie często z leksemem pseudokibic i konotowane negatywnie mogą być uznane jako ekwiwalenty niemieckich kolokacji leksemów Fan i Fußballfan, a mianowicie gewaltbereit 'gotowy do przemocy', aufgebracht 'zdenerwowany, rozwścieczony', gewalttätig 'brutalny, agresywny'.

Tabela 8. Czasowniki z leksemem pseudokibic w funkcji podmiotu

\begin{tabular}{|c|l|c|}
\hline Lp. & \multicolumn{1}{|c|}{ Adjektiv } & LogDice \\
\hline 1. & (z)demolować & 5,9 \\
\hline 2. & wtargnąć & 5,8 \\
\hline 3. & obrzucić & 5,1 \\
\hline 4. & wszczynać & 4,8 \\
\hline 5. & zakłócić & 4,5 \\
\hline 6. & zetrzeć (się) & 4,2 \\
\hline 7. & sympatyzować & 4,1 \\
\hline 8. & zaatakować & 4,1 \\
\hline 9. & wbiec & 3,9 \\
\hline 10. & rozrabiać & 3,8 \\
\hline
\end{tabular}

Źródło: opracowanie własne na podstawie sketchengine.eu

Zaobserwowana korelacja kolokacji nacechowanych negatywnie i współwystępujących zarówno z leksemem niemieckim Fußballfan, jak i polskim pseudokibic (ale nie kibic) pojawia się również w porównaniu współwystępujących czasowników (tab. 8). Czasowniki i zwroty werbonominalne wszczynać (rozróbę), wszczynać (awanturę), wtargnać i zaatakować są funkcjonalnymi ekwiwalentami niemieckich czasowników randalieren i stürmen (por. tab. 3). Jednocześnie zauważyć należy, że nie występują one wśród najczęstszych kolokacji leksemu kibic (por. tab. 4). Powyższą ekwiwalencję funkcjonalną ilustrują poniższe pary zdań dla języka niemieckiego i polskiego.

[5] Kibice piłkarscy zachowywali się agresywnie podczas podróży dwoma pociagami specjalnymi na mecz Bundesligi do Kolonii („Die Zeit”, 26 XI 2011).

[6] Z kolei pseudokibice Śląska wszczynali awantury na ulicach Lubina na długo przed meczem (sport.pl, 21 VI 2012). 
[7] Gdy kibice piłkarscy latem 2006 roku ruszyli szturmem na stadion olimpijski, [...] („Berliner Zeitung”, 10 III 2005).

[8] Po tym jak warszawianie zdobyli trofeum, na murawe wtargnęli pseudokibice obu drużyn (se.pl, 26 VI 2012).

Powyższą konwergencję pomiędzy pewną częścią kolokacji współwystępujących z leksemem Fußballfan i kolokacjami leksemu pseudokibic stwierdza się również w analizie kookurencji leksemu pseudokibic z ograniczeniem do współwystępujących czasowników z leksemem pseudokibic w syntaktycznej funkcji dopełnienia, por. tab. 9.

Tabela 9. Czasowniki z leksemem pseudokibic w funkcji dopełnienia

\begin{tabular}{|c|l|c|}
\hline Lp. & \multicolumn{1}{|c|}{ Adjektiv } & LogDice \\
\hline 1. & rozpracowywać & 5,4 \\
\hline 2. & zwaśnić & 4,9 \\
\hline 3. & zatrzymać & 4,8 \\
\hline 4. & rozwydrzyć & 4,4 \\
\hline 5. & zwalczyć & 4,3 \\
\hline 6. & rozwścieczyć & 4,3 \\
\hline 7. & poręczyć & 3,4 \\
\hline 8. & udaremnić & 3,3 \\
\hline 9. & zidentyfikować & 3,2 \\
\hline 10. & ukarać & 2,9 \\
\hline
\end{tabular}

Źródło: opracowanie własne na podstawie sketchengine.eu

Czasowniki z największą częstotliwością współwystępowania z leksemem pseudokibic jako dopełnienia - rozpracowywać, zatrzymać, udaremnić, zidentyfikować, ukarać (patrz tab. 9) - odnoszą się przede wszystkim do działań policji i wymiaru sprawiedliwości i wskazują na ekwiwalencję funkcjonalną z czasownikami współwystępującymi z niemieckim Fussballfani Fan (tab. 5), a co ilustrują poniższe przykłady użycia pary ekwiwalentów festnehmen - zatrzymać.

[9] Policja aresztowała w Jenie dwunastu agresywnych berlińskich kibiców piłkarskich („Berliner Zeitung”, 19 X 1999). 
[10] Po wtorkowych zajściach policja zatrzymała 184 pseudokibiców, w większości polskich i rosyjskich („Rzeczpospolita”, 16 VI 2012).

Dalsze pary ekwiwalentów przedstawiają m.in. pary verurteilen 'skazywać'- ukarać oraz vorgehenn (gegen) 'postępować (przeciw)' - zwalczać.

\section{Podsumowanie}

Przedstawiona analiza leksykograficzna leksemów Fan i kibic wskazuje na specyfikę kulturową nazewnictwa sympatyków piłki nożnej - na konwergencję i ekwiwalencję, jak w przypadku Fußballfan - kibic piłkarski, oraz na określenia specyficzne dla danego języka i danej kultury, np. Kuttenfan w języku niemieckim i szalikowiec czy piknik w języku polskim. Określenie te wymagają zatem szczegółowego i kulturowego wyjaśnienia w opisie leksykograficznym. Pełna ekwiwalencja (w sensie W. Kollera) występuje w parach internacjonalizmów, np. Ultras - ultras, oraz „uniwersalnych” określeniach grup kibicowskich, np. Allesfahrer - wyjazdowicz.

Korpusowa analiza kookurencji (kolokacji), która przeprowadzona została na materiale korpusu DWDS dla języka niemieckiego i korpusu plTenTen dla języka polskiego, służy jako metoda ustalenia ekwiwalencji funkcjonalnej. Z perspektywy ekwiwalencji funkcjonalnej (Dobrovol'jskij 2013: 277) jako pełne ekwiwalenty uznaje się środki językowe - wyrazy, grupy wyrazowe, które występują w tym samym otoczeniu językowym.

Powyższa analiza pozwala na stwierdzenie dwóch par ekwiwalentów wykazujących identyczną kookurencję: Fußballfan $1 / F^{1} n^{1}$ - kibic oraz Fußballfan ${ }^{2} / F n^{2}$ - pseudokibic. Dla pierwszej pary ekwiwalencji Fußball$f a n^{1} / F n^{1}$ - kibic charakterystyczne są następujące kolokacje:

- Fußballfan ist begeistert, treu und eingefleischt / kibic jest fanatyczny, wierny i prawdziwy;

- Fußballfanwartet, fiebert mit, pilgert/ kibic czeka, dopinguje, przychodzi;

- [ein Spieler/eine Mannschaft kann] einen Fußballfan begeistern, enttäuschen, sich [bei einem Fußballfan] bedanken/ [zawodnicy/drużyna może] kibicowi sprawić radość, kibica zawieść, kibicowi podziękować.

Natomiast dla pary ekwiwalentów Fußballfan $2 / \mathrm{Fan}_{2}$ - pseudokibic kookurencjami o najwyższej częstotliwości współwystępowania są:

- Fußballfan ist gewalttätig und aufgebracht / pseudokibic jest agresywny i rozjuszony; 
- Fußballfanrandaliert, stürmtauf den Rasen stürmen/ pseudokibic wszczyna rozrubę/awantury, wtarga na murawę;

- [einen Fußballfan kann man] festnehmen, verurteilen/ [pseudokibica można] zatrzymać, ukarać.

Tym samym analizy kookurencji leksemów Fan, Fußballfan, kibic i pseudokibic wskazują na tzw. częściową ekwiwalencję (partielle Äquivalenzwg W. Sternemanna) w relacji Fußballfan - kibic/pseudokibic.

\begin{tabular}{|c|c|}
\hline (Fußball-)Fan & kibic \\
\hline Fußballrowdy / Hooligan & pseudokibic \\
\hline
\end{tabular}

Podsumowując, stwierdzić można, że korpusowa analiza kookurencji przedstawia w studiach kontrastywnych metodę, która pozwala na ustalenie ekwiwalencji funkcjonalnej - w sensie D. Dobrovol'skiego i C. Mellado Blanco między wyrazami i grupami wyrazów w sposób empiryczny, obiektywny i obiektywizujący. Przykłady wykorzystania kookurencji dla ustalenia ekwiwalencji związków wielowyrazowych zawierają prace ukazujące ekwiwalencję zwrotów werbonominalnych w porównaniu niemieckopolskim (Taborek 2020; Piątkowski 2021) i frazeologizmów w porównaniu niemiecko-hiszpańskim (Mellado Blanco 2019). Ekwiwalencja funkcjonalna ustalana w powyższy sposób spełnia kryterium analizy języka w jego użyciu (usage-based) i może znaleźć szerokie zastosowanie $\mathrm{w}$ procesie i opisie leksykograficznym, translatorycznym czy dydaktycznym.

\section{Literatura}

Bubenhofer N. (2015): Muster aus korpuslinguistischer Sicht, w: Handbuch Satz, Äußerung, Ch. Dürscheid\& H.G. Schneider et. al., Berlin.

Burkhardt A. (2006): Wörterbuch der Fußballsprache, Göttingen.

Bußmann H. (2008): Lexikon der Sprachwissenschaft, Stuttgart.

Dobrovol'skij D. (2015): Introduction, „International Journal of Lexicography” 28(3), s. 275-278.

Duda H. (2008): The words 'kibic' (Sports fan) and 'pseudokibic' (hooligan) in Polish. Remarks on names of sports enthusiasts used during sporting events, $\mathrm{w}$ : The linguistics of football, (red.) Lavrić, E.i in.,Tübingen. 
DWDS = Digitales Wörterbuch der deutschen Sprache. Das Wortauskunftssystem zur deutschen Sprache in Geschichte und Gegenwart, (red.) Berlin-Brandenburgischen Akademie der Wissenschaften, https://www.dwds.de/, dostęp: 11 II 2020.

Jakubowski B. (2007): Pseudopodia a pseudokibice, „Język Polski” 87, s. 224-226.

Janik M. (2018): Ocena stabilności ekspresywnej leksemu kibol „Orbis Linguarum” 51, s. $67-84$.

Mellado Blanco C. (2019): Phrasem-Konstruktionen kontrastiv Deutsch-Spanisch: ein korpusbasiertes Beschreibungsmodell anhand ironischer Vergleiche. „Yearbook of Phraseology" 10(1), s. 65-88.

Piątkowski Ł. (2021): Kookkurrenz, syntagmatische Muster und lexikographische Darstellung der Funktionsverbgefüge im deutsch-polnischen Vergleich. Niepublikowana dysertacja doktorska, Uniwersytet im. Adama Mickiewicza w Poznaniu.

Pilz G. (2005): Vom Kuttenfan und Hooliganzum Ultra und Hooltra - Wandel des Zuschauerverhaltens im Profifußball, „Die Polizei” 11/2005, s. 6-12.

Taborek J. (2020): Kookkurrenz und syntagmatische Muster der Funktionsverbgefüge aus kontrastiver deutsch-polnischer Sicht am Beispiel in Not geraten, w: Funktionsverbgefüge im Fokus: Theoretische, didaktische und kontrastive Perspektiven, (red.) S. De Knop \& M. Hermann et al., Berlin.

Taborek J. (2021): Zu Bezeichnungen (Fußball-) Fan, kibic und pseudokibic im deutsch-polnischen Vergleich aus Perspektive der Kookkurrenz, w: Fankultur und Fankommunikation in nationalen und transnationalen Diskursen, (red.) R. Beliutin \& A. Burkhardt et al., Frankfurt n. M.

WSJP = Wielki słownik języka polskiego <http://www.wsjp.pl>

Żmigrodzki P. (2007): Dopisek do artykułu Bronisława Jakubowskiego, Pseudopodia a pseudokibice, „Język Polski” 87, s. 226.

\section{Fan, Fußballfan, kibic and pseudokibic as functional equivalents from the perspective of co-occurrence in German and Polish}

The aim of the paper is to establish the functional equivalence between the terms 'football fan' in German and Polish. Functional equivalence presupposes that lexemes occur in the two languages in a convergent syntagmatic environment. The analysis of co-occurring lexemes will be based on establishing the correlations of German units using the DWDS Wortprofil tool and the DWDS corpus, and for the Polish language - WordSketch and the plTenTen corpus. Detailed analysis and comparisons of co-occurrence (co-occurring adjective and verb groups with the highest frequency are analysed according to their syntactic functions and semantic groups) allows for establishing partial equivalence between the analysed lexemes and to state that the German terms 'Fan' and 'Fußballfan' cover the meaning of the neutral lexeme 'kibic' as well as the meaning of the lexeme 'pseudokibic' with negative connotations

Keywords: co-occurrence, collocation, sports language, functional equivalence Słowa kluczowe: kookurencja, kolokacja, język sportu, ekwiwalencja funkcjonalna 